\title{
Correction to: A new short-term aging model for asphalt binders based on rheological activation energy
}

\author{
Derun Zhang • Bjorn Birgisson · Xue Luo $\cdot$ Ibrahim Onifade
}

Published online: 6 July 2020

(C) The Author(s) 2020

\section{Correction to:}

Materials and Structures (2019) 52:68

https://doi.org/10.1617/s11527-019-1364-7

The article "A new short-term aging model for asphalt binders based on rheological activation energy", written by "Derun Zhang, Bjorn Birgisson, Xue Luo, Ibrahim Onifade", was originally published electronically on the publisher's Internet portal (currently SpringerLink) on 24 June 2019 without open access. The copyright of the article changed in May 2020 to The Author(s) 2020 and the article is forthwith distributed under the terms of the Creative Commons Attribution 4.0 International License (http://

The original article can be found online at https:// doi.org/10.1617/s11527-019-1364-7.

D. Zhang $(\bowtie) \cdot$ B. Birgisson $\cdot$ I. Onifade

Zachry Department of Civil Engineering, Texas A\&M

University, 3136 TAMU, College Station,

TX 77843, USA

e-mail: derunzhang2018@gmail.com

B. Birgisson

e-mail: bjorn.birgisson@tamu.edu

I. Onifade

e-mail: onifade@tamu.edu

X. Luo

College of Civil Engineering and Architecture, Zhejiang

University, 866 Yuhangtang Road, An-zhong Bldg.,

Hangzhou 310058, China

e-mail: xueluo@zju.edu.cn creativecommons.org/licenses/by/4.0/), which permits use, duplication, adaptation, distribution and reproduction in any medium or format, as long as you give appropriate credit to the original author(s) and the source, provide a link to the Creative Commons license and indicate if changes were made.

Open Access This article is distributed under the terms of the Creative Commons Attribution 4.0 International License (http://creativecommons.org/ licenses/by/4.0/), which permits unrestricted use, distribution, and reproduction in any medium, provided you give appropriate credit to the original author(s) and the source, provide a link to the Creative Commons license, and indicate if changes were made.

Publisher's Note Springer Nature remains neutral with regard to jurisdictional claims in published maps and institutional affiliations. 